Marta Maskey-Warzęchowska', Krzysztof Karwat', Benedykt Szczepankiewicz' ${ }^{2}$, Renata Langfort' ${ }^{3}$, Małgorzata Szołkowska ${ }^{3}$, Ryszarda Chazan'

'Department of Internal Medicine, Pneumonology and Allergology, Medical University of Warsaw

2Department of Pathology, Medical University of Warsaw

${ }^{3}$ Department of Pathology, Institute for Tuberculosis and Lung Diseases, Warsaw

\title{
Leflunomide-induced acute interstitial pneumonia in a patient treated for rheumatoid arthritis
}

\author{
Ostre śródmiąższowe zapalenie płuc wywołane leflunomidem u chorego \\ na reumatoidalne zapalenie stawów
}

The authors declare no finacial disclosure

\begin{abstract}
Leflunomide is a disease-modifying anti-rheumatic drug that is used in patients with rheumatoid arthritis (RA), who do not respond well to standard RA treatment. Leflunomide therapy may, however, be related with significant pulmonary complications in predisposed individuals. We present a patient with RA treated with leflunomide, in whom leflunomide lung injury had a fatal outcome. Potential risk factors for pulmonary complications of leflunomide treatment and the management of patients with leflunomide lung injury are discussed.
\end{abstract}

Key words: interstitial pneumonia, rheumatoid arthritis, leflunomide

Pneumonol. Alergol. Pol. 2015; 83: 50-54

\section{Streszczenie}

Leflunomid należy do leków przeciwreumatycznych modyfikujących przebieg choroby. Jest on stosowany u chorych z reumatoidalnym zapaleniem stawów, u których leczenie pierwszej linii było nieskuteczne. Leczenie leflunomidem może być jednak związane z istotnymi powikłaniami płucnymi, zwłaszcza u osób predysponowanych. Autorzy przedstawiają opis przypadku chorego na reumatoidalne zapalenie stawów leczonego leflunomidem, u ktorego wystąpiły powikłania ze strony układu oddechowego. Omówiono czynniki ryzyka wystąpienia uszkodzenia płuc w przebiegu leczenia tym preparatem oraz sposób postępowania w przypadku ich wystąpienia.

Słowa kluczowe: choroba śródmiąższowa płuc, reumatoidalne zapalenie stawów, leflunomid

Pneumonol. Alergol. Pol. 2015; 83: 50-54

\section{Introduction}

Rheumatoid arthritis (RA) is a systemic disease that frequently involves the respiratory system. Interstitial lung disease (ILD) is one of the leading causes of RA-related mortality [1]. Disease-modifying anti-rheumatic drugs (DMARDs) have been shown to have a positive impact on the course of the disease.

Leflunomide, a DMARD introduced more than a decade ago, was reported to alleviate RA symptoms and retard radiological progression of the disease [2]. However, adverse-event moni-

Address for correspondence: Krzysztof Karwat, MD, Katedra i Klinika Chorób Wewnętrznych, Pneumonologii i Alergologii, Warszawski Uniwersytet Medyczny,

02-097 Warszawa, ul. Banacha 1a, e-mail: krzysztof.karwat@wum.edu.pl

DOI: 10.5603/PiAP.2015.0007

Received 6.05.2014

Copyright (C) 2015 PTChP

ISSN 0867-7077 
toring revealed an increased risk of interstitial lung disease in predisposed individuals. These particularly included subjects with pre-existing interstitial lung disease or other lung diseases and a history of methotrexate treatment [3].

We present a case of a 54-year-old male with a RA-related interstitial lung disease treated with leflunomide, who had previously undergone methotrexate therapy and who developed rapid ILD progression.

\section{Case report}

A 54-year-old male with rheumatoid arthritis and a relevant smoking history (30 packyears) was admitted to our department due to rapidly progressing dyspnoea and dry cough. Data on the course of RA came exclusively from the patient's family and a single discharge card. RA had been diagnosed 20 years ago and had been treated with methotrexate and steroids. The treatment had been withdrawn 6 months previously because of the progression of lung fibrosis, and was replaced by azathioprine; however, this therapy was also terminated due to drug intolerance. Two months prior to the present hospitalisation the patient's consulting rheumatologist decided to initiate leflunomide therapy at a daily dosage of $20 \mathrm{mg}$, and the patient had been receiving leflunomide up to the day of admission.

On admission the patient was in a severe general condition, afebrile, with tachypnoe $29 / \mathrm{min}$, heart rate $100 / \mathrm{min}$, and blood pressure 100/80 mm Hg. On auscultation, crackles in the middle and basal lung areas were found. The analysis of arterial blood gases revealed hypoxaemia $\left(\mathrm{PaO}_{2}\right.$ $42.1 \mathrm{~mm} \mathrm{Hg})$ and hypocapnia $\left(\mathrm{PaCO}_{2} 23.2 \mathrm{~mm}\right.$ $\mathrm{Hg}$ ); other relevant laboratory findings included elevated levels of C-reactive protein $(259 \mathrm{mg} / \mathrm{L}$, normal range $0-10 \mathrm{mg} / \mathrm{L}$ ), procalcitonin (0.56 ng/ $\mathrm{ml}$, normal range $0-0.5 \mathrm{ng} / \mathrm{ml})$, d-dimer (1888 $\mathrm{ng} / \mathrm{mL}$, normal range $0-500 \mathrm{ng} / \mathrm{mL}$ ), creatinine (1.67 mg/dL, normal range $0.5-1.1$ ) and increased activity of troponin $(1.88 \mathrm{ng} / \mathrm{mL}$, normal range 0.0-0.1 ng/mL), transaminases (ALT $172 \mathrm{U} / \mathrm{L}$ and AST $205 \mathrm{U} / \mathrm{L}$, normal range 7-56 U/L and 5-40 U/L, respectively), and natriuretic peptide (747 pg/mL, normal range $0-125 \mathrm{pg} / \mathrm{mL}$ ). The leukocyte count was normal, but an increased neutrophil count and decreased lymphocyte count were observed $(86.3 \%$ and $8.0 \%$, respectively). The remaining laboratory findings were unremarkable. The chest radiograph revealed bilateral interstitial opacities, more pronounced in the left lung. Spiral computed tomography of

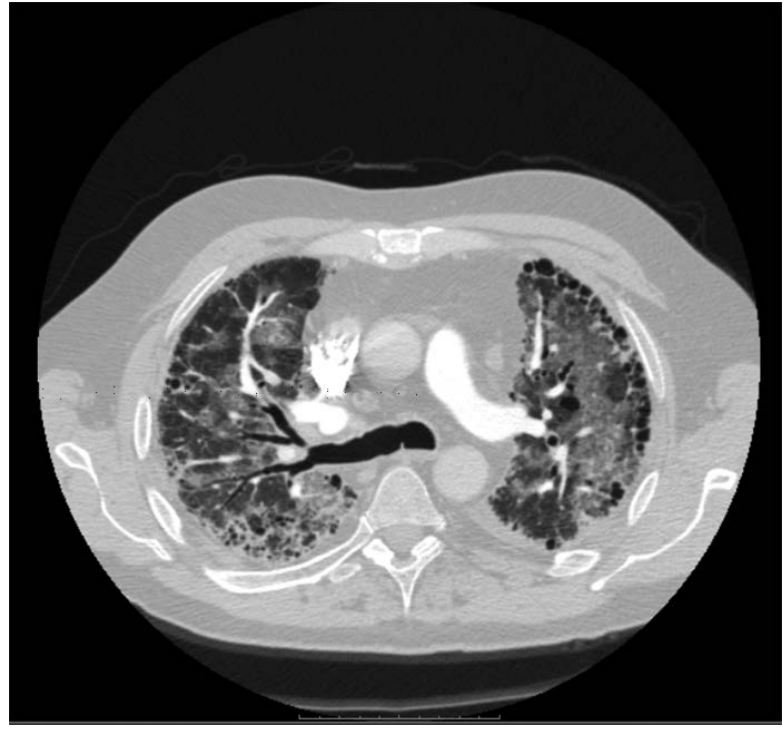

Figure 1. CT scan with diffuse ground glass opacities with basal subpleural honeycombing in both lungs

the chest did not confirm pulmonary embolism; however, diffuse ground glass opacities in both lungs with basal subpleural honeycombing was demonstrated, suggesting an active parenchymal inflammation (Fig. 1). ECG showed negative T waves in the III, aVF, and V1 to V5 leads, echocardiography revealed right ventricle overload, tricuspid regurgitation (tricuspid insufficiency pressure gradient $55 \mathrm{~mm} \mathrm{Hg}$ ) with right ventricular free wall hypokinesis and an acceleration time (AcT) of $80 \mathrm{~ms}$; no abnormal left ventricle wall contractility was detected.

Leflunomide was discontinued. The patient received oxygen therapy, systemic steroids (intravenous methylprednisolone $62.5 \mathrm{mg}$ bid), mucolytics, and antibiotic therapy with intravenous amoxicillin/clavulanic acid. As no marked improvement was observed within the first three days of treatment, co-amoxiclav was by replaced by ceftriaxone with co-trimoxazole and fluconazole. Serologic tests for Epstein-Barr virus, cytomegalovirus, and adeno-, astro-, nora-, and rotaviruses were negative. Sputum cultures showed physiological upper airway flora; blood cultures were negative.

The modification of antimicrobial treatment resulted in five days of stabilisation. However, on the $9^{\text {th }}$ day after admission the patient's condition worsened and he required mechanical ventilation. The chest radiograph performed at that time showed progression of the interstitial opacities. The dose of methylprednisolone was doubled (250 mg once daily) and cyclophosphamide (100 mg once daily) was initiated, but no improvement 
was noted. The patient died on the $16^{\text {th }}$ day of hospitalisation.

Gross autopsy findings were massive oedema and congestion with fibrosis of the lungs, localised mainly in the lower lobes. Microscopic features of diffuse alveolar damage were found, mostly organising phase with fibrosis of interalveolar septa. However, foci of active process with formation of hyaline membranes were also noted. Additionally, foci of invasive (Grocott stain) aspergillosis, haemorrhagic infarcts, lobular pneumonia, and acute bronchitis were revealed (Fig. 2).

\section{Discussion}

Respiratory involvement is the second leading cause of mortality in rheumatoid arthritis following cardiovascular diseases [1, 4]. Respiratory manifestations of RA include the following: pulmonary nodules, bronchiectases, bronchiolitis, pleural involvement and interstitial lung diseases, and, finally, infections related to immunosuppressive treatment [5, 6, 7]. The lifetime risk of RA-related interstitial lung disease is estimated at $7.7 \%$ and is related with a threefold higher RA mortality [7]. It is more frequent in males, in patients with late RA onset, and increases with RA severity. However, for evident reasons, these studies were performed in patients receiving RA treatment, and the potential lung toxicity of anti -rheumatic drugs cannot be excluded.

Leflunomide was licensed for the treatment of rheumatoid arthritis more than 10 years ago [8]. Since then, surveillance studies have carefully analysed its effectiveness and potential side effects. After alarming reports coming from Japan on 5 deaths in 16 RA patients who had received this drug [9], lung toxicity remains one of the major concerns related to leflunomide therapy. Ju et al. found an ILD incidence of $1 \%$ in a group of 1,010 RA patients treated with leflunomide in the Korean population [10]. Similar data were reported by Sawada et al., who estimated the prevalence of ILD to be $1.2 \%$ in Japanese patients with RA receiving leflunomide [3]. However, the exact relation between leflunomide use and ILD occurrence is being discussed. Studies published to date do not to clarify whether the increased risk of newly developed ILD or exacerbation of pre-existing RA-ILD is related to leflunomide itself or to RA progression. The authors indicate that patients with a history of chronic lung disease, pre-existing ILD, and prior methotrexate use are at a higher risk of developing ILD during leflu-
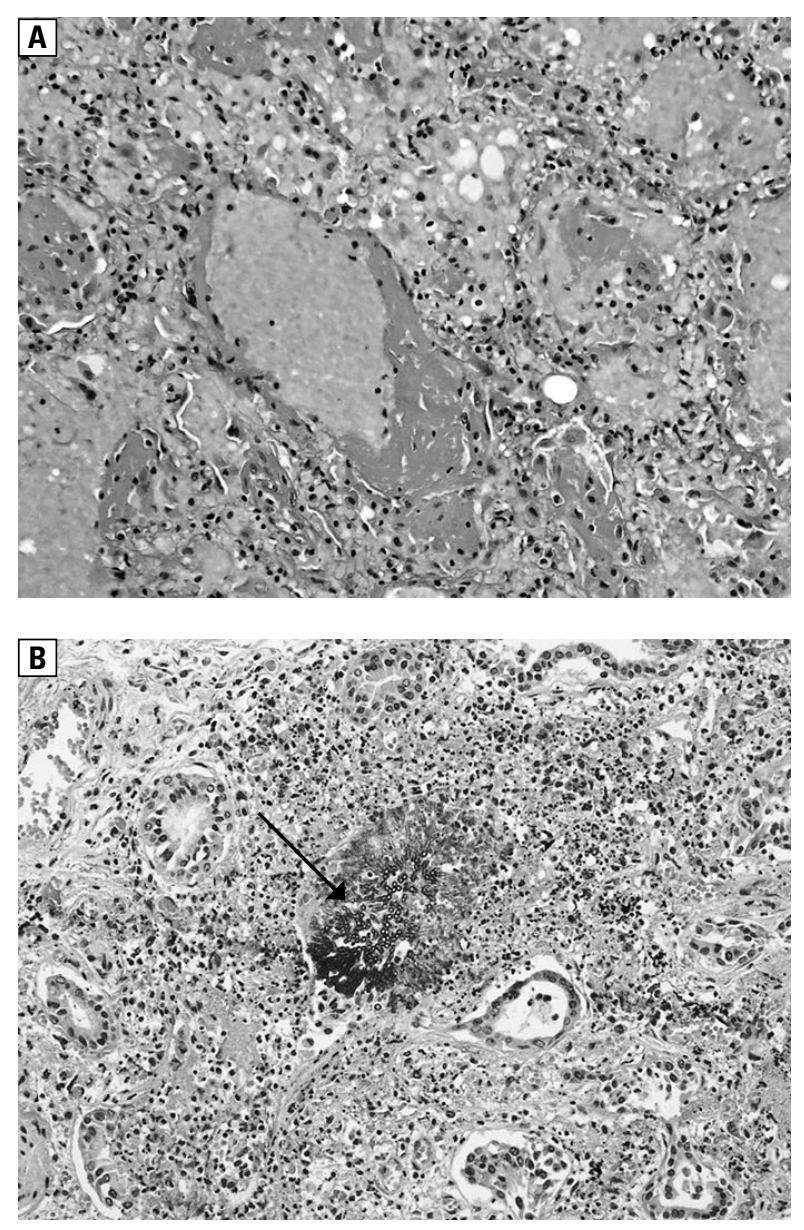

Figure 2. Histopathological appearance of the lung; $A-$ diffuse alveolar damage pattern black hyaline membrane formation; $\mathrm{B}$ - Grocott stain with evidence of Aspergillus infection (white arrow)

\section{Table 1. Factors predisposing to leflunomide-related interstitial lung disease in patients with rheuma- toid arthritis $[3,10,11]$}

\begin{tabular}{l}
$\begin{array}{l}\text { Risk factors for the development of leflunomide-related } \\
\text { disease in RA patients }\end{array}$ \\
\hline Male sex \\
Smoking \\
Long RA duration \\
History of chronic lung disease \\
Pre-existing interstitial lung disease \\
Prior methotrexate use \\
Asian origin? \\
\hline
\end{tabular}

nomide treatment (Table 1) [3, 10, 11]. Suissa et al. found that RA patients without any of the above-mentioned risk factors did not have a higher probability of ILD with leflunomide use [11].

Our patient had several risk factors for leflunomide-related ILD: male sex, a relevant smoking 
history, and long RA duration with a high disease activity, which imposed treatment modifications. Moreover, he had an eight-year history of RA-ILD and had been receiving methotrexate prior to leflunomide administration, both of which increase the risk of ILD development/exacerbation during leflunomide use. The first symptoms of lung injury appeared after nine weeks of leflunomide therapy. This time interval concurs with that reported by Chikura et al., who performed an analysis of 32 cases of leflunomide-induced lung injury and demonstrated that this condition usually occurs within 20 weeks from the onset of leflunomide administration [12]. The time relation between ILD progression and leflunomide use, ineffective antimicrobial treatment, and lack of evidence for viral infection in our patient indicated an association between ILD and leflunomide.

Leflunomide discontinuation is a cornerstone in the management of leflunomide-induced lung injury; however, no particular therapeutic algorithm has been established to date. Chikura et al. found that $75 \%$ of the reviewed cases had received steroids, $31 \%$ had received antimicrobial treatment, and $22 \%$ were treated with both steroids and antibiotics [12]. The elimination of leflunomide may be accelerated by cholestyramine, and this is a very promising treatment option [2, 12, 13]. Wong et al. reported a case of successful treatment with cholestyramine in monotherapy administered orally in a dose of $8 \mathrm{~g}$ three times daily [14], but further convincing data on the efficacy of this drug in the treatment of leflunomide-induced lung injury are required. In a recent review by R. Raj and K. Nugent, the recommended approach is that of leflunomide washout with cholestyramine; activated charcoal (50 mg every six hours for 24 hours) may also be considered to enhance leflunomide elimination. Nevertheless, the same authors present data that show that leflunomide discontinuation along with systemic steroids is the most frequently applied treatment [15].

Our patient presented a temporary response to combined therapy with steroids and antibiotics. The initial improvement suggested respiratory infection as the underlying cause of the patient's condition, regardless of leflunomide discontinuation, as leflunomide is characterised by a half-life of $1-4$ weeks [14]. That is why cholestyramine washout was not applied. The treatment had to be verified due to the patient's deterioration after a five-day period of stability. We subsequently chose cyclophosphamide, which is potentially capable of inhibiting lung fibrosis, for add-on therapy as the patient had reported azathioprine intolerance. No data on the effectiveness of cyclophosphamide in leflunomide-induced lung injury are available. Unfortunately, an increase in the steroid dose and the addition of cyclophosphamide had no effect.

Autopsy findings revealed DAD superimposed on long-standing interstitial lung disease. The pathomechanism leading to DAD in our case is complex with at least three potential contributing factors: Aspergillus infection, leflunomide treatment, and RA itself. Ochi et al. [13] described a 75-year-old patient with RA who developed acute interstitial pneumonia 45 days after the onset of leflunomide therapy, and who had a very similar histopathological appearance of the lung, including features of Aspergillus infection. The probability of pulmonary aspergillosis in our patient seemed low; the radiological appearance of the chest was not typical for invasive Aspergillus infection (usually presenting as nodular lesions with a rim of ground glass - the so-called "halo sign" or the air crescent sign). Sputum cultures were negative and the patient's condition did not allow bronchoalveolar lavage, so BAL fluid galactomannan and Aspergillus specific PCR could not be evaluated. Serum galactomannan and 1-D $\beta$ glucan were not assessed. Of note, the sensitivity and specificity of the above-mentioned serological and molecular methods in the diagnosis of invasive aspergillosis are still being discussed $[16,17]$. Despite progress in the diagnostics of fungal infections, up to $75 \%$ of invasive fungal diseases are diagnosed in autopsy [19]. In our patient, the presence of Aspergillus in the lungs causing tissue damage, a definite criterion of invasive aspergillosis, was also found in autopsy [17].

Chikura et al. have shown that there is $50 \%$ mortality in leflunomide-induced lung injury in patients with pre-existing RA-ILD [12]. According to Saito et al., a high serum CRP, lymphopaenia, hypoalbuminaemia, respiratory failure, and mechanical ventilation are also associated with a poor prognosis [18]. Most of these factors were present in our patient and may have contributed to the fatal outcome.

In conclusion, we advise caution in the use of leflunomide in RA patients with prior methotrexate therapy or pre-existing interstitial lung disease, because of the elevated risk of lung injury, a rare but potentially life-threatening condition. There is need for an effective diagnostic and treatment algorithm to improve the final outcome in patients with leflunomide-induced lung injury. 


\section{Conflict of interest}

The authors declare no conflict of interest.

\section{References}

1. Kelly C., Hamilton J. What kills in rheumatoid arthritis? Rheumatology 2007; 46: 183-184.

2. Fox R., Helfgott S.M. Leflunomide in the treatment of rheumatoid arthritis. Up-to-Date 2013, www.uptodate.com

3. Sawada T., Inokuma S., Sato T. et al. Leflunomide-induced interstitial lung disease: prevalence and risk factors in Japanese patients with rheumatoid arthritis. Rheumatology 2009; 48: 1069-1072.

4. Young A., Koduri G., Batley M. et al. Mortality in rheumatoid arthritis. Increased in the early course of disease, in ischaemic heart disease and in pulmonary fibrosis. Rheumatology 2007; 46: $350-357$.

5. Tsuchiya Y., Takayanagi N., Sugiura H. et al. Lung diseases directly associated with rheumatoid arthritis and their relationship to outcome Eur. Respir. J. 2011; 37: 1411-1417.

6. Lake F.R. Drug-induced lung disease in rheumatoid arthritis. Up to Date 2013, www.uptodate.com

7. Bongartz T., Nannini C., Medina-Velasquez Y.F. Incidence and mortality of interstitial lung disease in rheumatoid arthritis: a population-based study. Arthritis Rheum. 2010; 62: 1583-1591

8. Alcorn N., Saunders S., Madhok R. Benefit-risk assessment of leflunomide. An appraisal of leflunomide in rheumatoid arthritis 10 years after licensing. Drug Saf. 2009; 32: 1123-1134.
9. McCurry J. Japan deaths spark concerns over arthritis drug. Lancet 2004, 363 (9407): 461

10. Ju J.H., Kim S.I., Lee J.H. et al. Risk of interstitial lung disease associated with leflunomide treatment in Korean patients with rheumatoid arthritis. Arthritis Rheum. 2007; 56: 2094-2096.

11. Suissa S., Hudson M., Ernst P. Leflunomide use and the risk of interstitial lung disease in rheumatoid arthritis. Arthritis Rheum. 2006; 54: 1435-1439.

12. Chikura B., Lane S., Dawson J.K. Clinical expression of leflunomide-induced pneumonitis. Rheumatology 2009; 48: 1065-1068.

13. Ochi S., Harigai M., Mizoguchi F. et al. Leflunomide-related acute interstitial pneumonia in two patients with rheumatoid arthrtitis: autopsy findings with a mosaic pattern of acute and organizing diffuse alveolar damage. Mod. Rheumatol. 2006; 16: 316-320.

14. Wong S.P., Chu C.M., Kan C.H. et al. Successful treatment of leflunomide-induced acute pneumonitis with cholestyramine wash-out therapy. J. Clin. Rheumatol. 2009; 15: 389-392.

15. Raj R., Nugent K. Leflunomide-induced interstitial lung disease (a systematic review). Sarcoidosis Vasc. Diffuse Lung Dis. 2013; 30: 167-176.

16. Kędziora K., Słomiński J.M., Gil K. et al. Inwazyjna grzybica kropidlakowa zatok przynosowych, płuc i mózgowia. Pneumonol. Alergol. Pol. 2008; 76: 400-406.

17. Beirao F., Araujo R. State of the art. Diagnostic of mold diseases: a practical guide for clinicians. Eur. J. Clin. Microbiol. Infect. Dis. 2013; 32: 3-9.

18. Saito T., Inokuma S., Sagawa A. et al. Factors associated with fatal outcome of leflunomide-induced lung injury in Japanese patients with rheumatoid arthritis. Rheumatology 2009; 48: $1265-1268$. 